\title{
A METHODOLOGY FOR THE PAINS OF UNIVERSALITY AT UNIVERSITY
}

\section{Summary}

Objectivity and respectful dialogic engagement is achieved by permitting mental discomfort: by uniting and keeping differences intact rather than erasing them. If that seems too uncomfortable an obligation, it supports the idea that the path to a "broader, or social, view" (Dewey 1907: 20) - the philologist's promise of universality - should at least be found at the highest level of learning, at university. The methodologies to reach it are also broad: ranging from the Aristotelian to the Deweyan. It is proposed that consideration of the methodologies and higher-order skills used at university begin with consideration of the end or perfection of things, so as not to lose sight of humanity.

Key words: university liberal arts education, higher-order skills, philology, constructivism, epistemology, dialogue, experience, networked learning, telos

This is a paper about liberal pains - the pains of the threat to the disinterested freedoms of traditional liberal arts education and the pain, mostly from a philological but also from a broader epistemic perspective, of having to defend the legitimacy and need for difference, even where it is uncomfortable, in the face of what Erich Auerbach foresaw as "leveling" forces (1969: 2; also see Dewey 1986: 203).

Speaking of philology, it is the philological attention to studying comparative methods, explanations of etymology, corpus analysis, and historical context that can speak, in an elderly voice like that of grandparents no one listens to anymore, to what is meant by "university". As dem-

Faculty of Philology, Studentski trg 1, 11000 Belgrade

greta.goetz@fil.bg.ac.rs 
onstrated by its historical pedigree, philology has as much of a claim on Hippocrates as do the scientific arts, for it is the philologist's work in textual criticism that determines which variant of a manuscript best approximates the author's original work. This aspect of philology can be said to have ceded today to the more general Nietzschean practice of "slow reading": "to read well, that is to say, to read slowly, deeply, looking cautiously before and aft" (Nietzsche 1982: 5).

In line with this cautious approach, one of Hippocrates' aphorisms warns: "Life is short, craft long, [...] experience treacherous, judgment difficult" (n.d.: 1.1). "Experience treacherous" - we will come back to that, as it provides an interesting counterpoint to methodologies that do not just incorporate experience, but privilege it above all else. Experience may indeed be necessary, but it is also treacherous, and definitely requires, if we seek to perfect it, more time than we may have in a single life, as Hippocrates suggests.

The philological method professionalized thousands of years ago at Alexandria included the cautious work of textual criticism described above, and is suggestive of the reflective exercise that contributes to learning. It also included literary criticism, or commentary. Where philology has viewed language as a means to disclose the nature or thought of man in different times and places, it has been to some extent a form of cultural study. ${ }^{1}$ I bring this up to say that philology, in its careful work of reading, includes a hermeneutical, or interpretive, component, which at once seeks to bring texts closer through comprehension, while respecting and maintaining their contextual, or cultural, differences. It is this aspect of philology that will be the central focus of this paper.

Among the philologists whose work has contributed to the legacy of literary philology is Erich Auerbach, who in Edward Said's words was

1 This remark is a reformulation of some of John Edwin Sandys' definitions (1903: 3). Note that he gives an overview of the complicated history of the word "philology" (1903: 1-13), and also see his remark on "modern philology", which is broadened to include the study of art: inscriptions, monuments... (1903: 11-13). The cultural component of philology was even recognized by Ferdinand de Saussere: "The early philologists sought especially correct, interpret, and comment upon written texts. Their studies also led to an interest in literary history, customs, institutions, etc." (1959: 1). Of course, he sought to end philology with his principles of structural linguistics (Banfield 2006: 96), but the point here is that the legacy of philology is acknowledged by thinkers who took this legacy in very different directions. 
in pursuit of a universal literature which "transcends national literatures without [...] destroying their individualities" (1969: 1). Auerbach wrote of philology as contributing to the inner history of mankind, creating a conception of man "unified in his multiplicity" (1969: 4). The "universal" in the title of this paper stems from this conception.

Man in all his multiplicity is not effective language for a grant proposal. It is an ethical definition of life in the grey areas of one branch of philology. It is costly - both financially and temporally. The endeavor seems bound to fail before it's begun; the community of scholars - a pipe dream, or the vaping of unemployed graduates.

But there are arguably opportunities for philology even today, which is not devoid of political implications, as we shall see. I will press on with this legacy also because university lecturers are known to be a pain.

And lecturers, despite the unfavorable word on the street of their draconian standards and great expectations, do sit down periodically to assess the minimum they want students to take from their courses. This can be described as backward design or course objectives: identifying the core ideas and skills students are to acquire or strengthen.

My objective for this paper is to suggest that an explicit task of higher education today needs to stress thinking skills that move beyond oversimplification and the reductionist trend to manipulate knowledge to fit preconceived expectations or agendas. ${ }^{2}$ It is the place of higher education to provide transformative encounters with new knowledge. I focused on Nietzsche's definition of close reading at the beginning of this paper because he describes the position of the reader as one who is open before an unknown in a text: to read well, one must read "with doors left open, with delicate eyes and fingers" (emphasis added). This openness can be described as a willingness to be receptive to the transformative potential of the dialogic aspect of a text, which can bring us something new, something puzzling we have not encountered before. ${ }^{3}$

2 The range of such manifestations includes "organizational trauma" which can affect even educational organizations. See Shana Hormann and Pat Vivian: 2013 for general definitions, including how closed boundaries and limiting attitudes affects groups of people assembled within an organization.

3 Hans-Georg Gadamer writes that in order to understand the text itself, "the interpreter's own thoughts too have gone into re-awakening the text's meaning ... not as a personal standpoint that he maintains or enforces, but more as an opinion and a possibility that 
Openness and receptiveness to difference are thus essential to the work of the philologist. They are also important to the development of epistemic fluency, which is to say: learning how to learn how meaning is negotiated or created in different contexts. This can be further expanded to mean: learning how to learn how an individual has a role in the negotiation of meaning in different contexts. This is important to civic life, and it is worth remembering at this juncture that the traditional goal, or end perfection, of a liberal arts university education, was to create better citizens. $^{4}$

The university education that seeks to cater to such an end perfection or $\tau \varepsilon \dot{\lambda}$ os (telos) necessarily involves a variety of different and interconnected higher-order skills. These can include the following (illustrated by how they can relate to philology):

- An awareness of what goes into the process of solving problems (such as the explanation, interpretation, application, etc. that goes into deciphering the meaning of a text);

- (dialogic) interaction (with texts, others, ideas);

- creativity and improvisation (seen through the 'suspension' of the immediate relation to reality as the attempt is made to understand something new, and seen through how historical texts require ever renewed comprehension, as the present is always changing $)^{5}$;

- knowledge building;

- reflection and critical thinking (this includes discernment);

one brings into play and puts at risk, and that helps one truly to make one's own what the text says." He described this as a "fusion of horizons": "We can now see that this is what takes place in conversation, in which something is expressed that is not only mine or my author's, but common" (2004: 390). There is a dialogic element to hermeneutics - or the recovery of meaning from a text. This is supported by Paul Ricoeur's "hermeneutic arc", which could be described as a dialogic interaction between life experience, text, and life, and moreover seeks to "integrate opposed attitudes of explanation and understanding within an overall conception of reading as the recovery of meaning" (1991: 60).

$4 \quad$ This follows Aristotle's notion of $\tau \varepsilon \dot{\lambda} \lambda$ ऽ (telos), or goal: humans alone have the potential for good, and ought to direct their lives in pursuit of the highest good: becoming just, selfcontrolled, courageous, ethical, happy. Ultimately, education was to produce good citizens (cf. Aristotle 1934b: VIII.1.1337a-b).

5 Support for these two ideas can be found in Gadamer: 'suspension' of immediate reality to apprehend something new, which he compares to 'fiction' (2004: 306), and the ever needful task of re-explaining the past in terms of the ever changing present (2004: 579). 
- what I shall term character bildung (as per Von Humoldt's understanding of the pedagogic role of bildung [2010: 57-61] - the inclusion of this skill in a paper on the tools that come to us through philology is defended by the implications of Ricoeur's hermeneutical arc [see fn. 3]; hermeneutics, though claimed by philosophers, is directly and historically related to the philologist's task);

- self-direction (as the individual ultimately navigates through the dialogic experience) ${ }^{6}$.

These higher-order skills can help students enter already ongoing conversations representative of different views, including the ongoing conversations of academic scholarship and "broader" society. As membership in the academic community requires making an original contribution to the ongoing conversations and not merely reproducing them, and as membership in broader society requires some degree of self-knowledge and direction, all of the multiple higher order skills in this list are important. They should emerge from the core of the discipline, challenge misconceptions, engage students, and ultimately extend beyond the course of university study to be applied in civic life.

To illustrate how these skills can be developed, let us take by way of example a course which has not traditionally belonged to the domain of philology but which can be approached through the lens of literary philology. Literary philology considers the conditions under which a given literature develops and strives to achieve historical synthesis, among other things (Auerbach 1969: 8-9, 12). Such a course could build on the receptive praxis described by Nietzsche: to read slowly and carefully, with openness - so, unconstrained by preconceived notions. It could seek to introduce, depending on student capabilities ${ }^{7}$ - and character - to include higher-order frameworks that are related to philology.

Examples of such frameworks include literary criticism and theory. On a more basic level, they can include elements of rhetoric, such as com-

$6 \quad$ It is noted that self-direction is initially facilitated.

7 As per Lev Vygotsky's zone of proximal development (ZPD): ZPD moving from what students are already capable of to what they are capable of with guidance - not expecting students to achieve what is beyond (or below) their current capabilities. 
parison and contrast or deliberative discourse, or analysis/production of speeches or multimedia content. Especially if a historical perspective is taken, many of these frameworks will reveal the heterogeneity of the collective culture as the elements of circumstance are multiple and constantly changing. A course prepared to view America as such a distinctive entity would deter students from making sweeping generalizations. In the words of Jacques Barzun (1991: 77):

Thus reading about the debate on the adoption of the U.S. Constitution or the struggles of the Protestant Reformation affords a vicarious experience which is formative, quite apart from what the memory may retain of the facts. And when the mind has grasped in several contexts the effect of circumstance, the nature of partisanship, the role of chance, and the influence of leaders and bunglers, the student of history who has discussed with others these potent imponderables may become not only a better judge of public policy and politicians, but also a more tolerant person.

Students who have been exposed to various dialogues and contexts are better-versed for civic life.

Rather than silence voices, any faculties of philology that are still left standing have the job to cultivate civil dialogue, accuracy, and academic maturation. But given that inter-and intra-departmental relations are not immune to petty politics and pride, academic maturation can sound, to some, as unrealistic as the Melians' plea that the Athenians treat them fairly because justice should belong to all (Thucydides 1910: V. 84-116). ${ }^{8}$

Giambattista Vico, an early rhetorician and philosopher who was a great influence on the philologist Erich Auerbach, wrote of academic matu-

8 Reference to this dialogue is being made in order to consider the Melians' right to independence, not the Periclean imperialism which is also represented in this dialogue. The Melian dialogue essentially presents a conflict between might - of the Athenians seeking to invade Melos, and right - the Melians' wish to remain independent of Athenian control. The Melian elders decide to risk rejecting peaceful concession to Athenian control in the hope that Lacedaemonian intervention will save them. The Melians were ultimately forced to surrender, after a siege in which Melian adult males were put to death, and women and children sold into slavery. Melos was then colonized by the Athenians. It is important to note that this conflict as presented by Thucydides, while defending Melian right to identity, is not necessarily critical of the Athenian rhetoric of the time, though it does seem to imply that empire and independence were bound to effect each other's demise. 
rity in his speech addressed to undergraduates. In it, he touts the benefits of wisdom, and advises that students not roll their eyes at what he is saying (1976: 892). In defending difference, he concedes that the different things that can be taught at university may be in flat contradiction to one another. Yet, this is a boon not a bane, he explains, as university education of this kind is not sectarian or over-specialized in a single period of human knowledge, which soon becomes obsolete and redundant; rather, different subjects lend to each other "wisdom" (that word again) "in its entirety".

Thus ... logic will free the reasoning power from false opinions; ... Rhetoric exists to ensure that the tongue does not betray nor fail the mind, nor the mind its theme; poetics to calm the uncontrolled turbulence of the imagination;

And so on (1976: 893-4). His list, in its entirety, pertains not just to philology, but also to metaphysics, ethics, geometry, and physics. His conception of university study can thus be compared to what we today call cross-disciplinary study. Difference is maintained, but held together in the shared discourse, or dialogue, of a community of university scholars.

This ideal dialogic community can be contrasted with communication from the media, which can seem to go "one way, from the center out toward the periphery" (Berry 2005: 122). Meanwhile, experience teaches that life is not so one-sided. For example, students can be asked to state their opinion on the subject matter of contested texts, before then being asked to defend or attack the texts, their roles assigned at random. This exercise gives students a form of practical experience: some students inevitably begin to see the fallibility of initial one-sided opinion, which is weaker than supported reasoning and can change on further evaluation or become more complex.

The move away from didacticism in education to expose students to practical experience is largely attributed in contemporary scholarship to John Dewey and his social ideals, though of course Aristotle had writ-

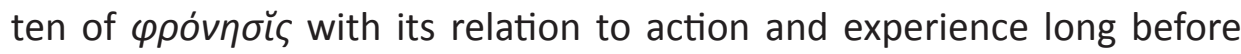
him (1944a: 6.8.6-6.89 and 2.1.1-2.1.4). ${ }^{9}$ Dewey also sought an educa-

9 Note, too, that Dewey, like Aristotle, sees the social and political implications of thought, and so the importance of providing a "good" education. 
tion that would develop individuals to their fullest potential (1986: 2023 ) and have practical merit. The practical exercises he conceived to that end, while designed to draw on students' interests, were not to pander to students but incite them to grow. The teacher was to operate "not as a magistrate set on high and possessed of arbitrary authority but as a friendly co-partner and guide in a common enterprise" (1986: 200). As such, while he considered this type of education "new", it bears the stamp of "old" Socratic maieutics: in the Meno, Socrates gives a slave guided assistance in "finding out the truth of the matter: for now he will push on in the search gladly" (1967b : 84b). It is of interest that Dewey dreamed up his pedagogy as a necessary response to industrialization (1986: 203) - for we are dealing with its apotheosis through globalization. It is curious, too, how well suited his student-centric, practical constructivist model is to the networked revolution to come out of our age of the internet, which has dramatically affected student attention spans, work habits, and assumptions.

The age of the internet has also brought new resources to instructors, ranging from readymade lesson plans to exposure to multiple halfbaked and other methodologies, which together contribute to the furthering of multiple truths, representations, perspectives, and realities by simply co-existing at this time. Such contradiction, as we have seen, was welcomed by Vico, who, by prompting the higher-order skill of synthesis through his counsel that wisdom be sought in its entirety, establishes a coherent learning environment. Dewey himself, aware of the new modes of teaching, notes the importance of establishing environments conducive to learning, otherwise "the young are left at the mercy of all the unorganized and casual forces that inevitably play upon them throughout life" (1986: 200,198). So the reference to baking with regards to halfbaked methodologies above is a nod to Dewey's cautionary advice that some structure is necessary for there to be development.

But it also a nod to Plato, whose Socrates compares sophistry to dainty fare (sometimes translated as 'pastry baking', so, not quite cooking), whereas what is really needed by the soul is words that cure (Plato 1967: 464d). Vico also addresses this topic: "You have come together here [at this university], ailing as you are in mind and soul, for the treatment, the healing, the perfecting of your better nature" (1976: 892, emphasis added). But not everyone would agree with such idealism today, nor even with Dewey's 
social idealism, which he phrases in more pragmatic terms. In The School and Society, he posits that society ought to want the same for its children as the wisest parents do, and bequeath to schools the full range of its past accomplishments in order to realize "better thoughts of itself" and possibilities in the future $(1907: 19) .{ }^{10}$ This vision is challenged today by the conception that tradition is an unnecessary burden to be dispensed with (this conception is often supported by anecdotal historical precedent, and of course seeks, covertly, to replace one tradition with another).

In a relativistic atmosphere, it becomes all the more apparent how dialogue and exchange depend on good will and a belief in the value of dialogue and exchange, despite the mental discomfort this may cause or the seeming impossibility of the endeavor. The elderly voice of philology, like the elderly Melians' appeal to the Athenians, asks that the common good form the basis of conversation. We know what happened to the Melians when this was not respected. We also know of the demise that met the Athenians shortly thereafter. We can further observe how a similar lack of good faith in the realm of contemporary politics quickly leads to a breakdown in civility.

To build an argument for the validity of dialogic skills in today's environment can be challenging in such contexts, but I shall cite one instance where they are valued, in an example of constructive networking.

In a project pioneered by Ineke Delies, PhD students work together with students at vocational colleges and the businesses the latter apprentice at in order to define problems needing innovation. Together, they navigate the 'landscape' (after Étienne Wenger) of myriad communities of practice (businesses, consumers, educators, learners, etc.). The interns learn by doing, and share their experience with the businesses they work for and with PhD students at research universities. These higher level institutions create a network of learning, conduct research, and oversee value-creation and the transfer of knowledge innovation (Delies 2017: 1740). It is a sophisticated and constructive application of problem-based learning, which perfectly suits the type of higher-level institution hosting such activities: one of applied science.

10 See the parallels with Aristotle (1934: VIII.1.1337a21-24). Note that Dewey writes that a school system that does not strive to enlarge a child's outlook in this way "destroys our democracy" (1907: 19). But rigorous schooling has been central to very different political groups, such as the late $18^{\text {th }}$, early $19^{\text {th }}$ century Federalist Party, proponents of which believed that it is the educated who are fit to govern society. 
Comparable constructivist learning projects that give students practical experience are instituted at faculties of philology. These can, for example, require students to translate texts used in workplaces, and can further be placed in a networked context by having other groups of students edit their work, as is the practice in the Trans-Atlantic and Pacific Project (TAPP; see Mousten et. al. 2018). But this has little to do with the discomfort of difference - unless this is explicitly included in the syllabus. The TAPP model, for one, strives to "become aware of the world community" in addition to giving "their students experience at working with source texts and their authors" (Maylath n.d.). Are instructors being a pain by complicating things by insisting on difference at a time when, at long last, the students graduating from liberal arts students with such problem-based experience no longer have to wear that T-shirt that reads: Will think for food? The promise of philology is precisely the pain of breadth: to fully know a language is to have truly taken the pains to know at least something about medicine, philosophy, art, etc. One who claims to be an English language specialist cannot claim total ignorance when confronted with the scientific references in Shakespeare's plays ${ }^{11}$ or claim to have never encountered technical jargon. In other words, philology, because of the fact that the languages it studies are used to talk about a full range of subjects, appears to encourage polymathy. By this I mean - if I am honest where I myself stand in this matter, philology requires of its students at least a willingness to be receptive to the languages of other studies, and the basic epistemic skills to deepen this knowledge if needed. According to the Viconian view of university education presented here, those working in other fields are also to strive for cross-disciplinary competence.

The reason I'm being a pain about the task of education also harkens back to that elderly voice of philology warning that "experience [is] treacherous", a warning that becomes all the more potent if we consider the sheer breadth of contexts to which that aphorism has been applied since it was first recorded. The very movement of the application of an aphorism from one field to another further reminds us of the permeability of knowledge and the need for a well-rounded education.

An understanding of Shakespeare requires some degree of fluency (this word is chosen deliberately here, by way of shorthand) in: diurnal rotation, the 1572 Stella Nova, the Danish court language (German), astrology, astronomy, foiling techniques, atomism - the list goes on. 
Cross-disciplinary skills will be engaged to further unpack how it is that experience may be deemed "treacherous". While it is true that $\tau \varepsilon \chi \chi v \eta$ (skills, crafts) - the kind of thing picked up in apprenticeship - forms the metaphorical basis of an understanding of the skill involved in the disinterested understanding of how to do something in a craft-like way, $\tau \varepsilon \dot{\chi} \chi v \eta$ remains stuck within the realm of experience because it cannot explain the nature of its own application (Plato, 1967: 464b-d). Explanation belongs not to $\tau \dot{\varepsilon} \chi v \eta$ but to $\dot{\pi} \pi \iota \tau \eta \dot{\mu} \mu \eta$. Pastry-baking is $\tau \dot{\varepsilon} \chi v \eta$; knowing how

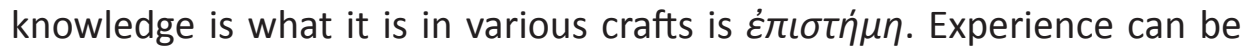
treacherous, at least according to one Platonic reading, because pleasure can insinuate itself as what is best, and can fool "boys or ... men as foolish as boys" that it indeed is of highest value to the body or to the soul when it comes to the politics of justice and legislation (Plato 1967: 464d; also see Aristotle 1944a: 1.4.1). This is to say that dialectical, reflective practice is crucial if experience - or the attempt to give a practical demonstration of knowledge or skill in a particular situation (as per the word $\pi \varepsilon \iota \rho \dot{\alpha} \omega$, translated as "experience" in the Hippocratic aphorism) - is to be beneficial: Hippocrates warns that we are already short on time. Reflective praxis is commonly adopted in new iterations of Deweyan constructivism in networked learning, such as Delies' professorship program. But such reflection is not - necessarily - disinterested...

The old voice of philology continues to talk - what a pain! (No wonder relativists abandon truth claims and deny the existence of universal meaning.) The old voice of philology, speaking from its literary legacy, wishes to recount a story about the merit of disinterested reflection. Once upon a time, Plato wanted to contemplate the pedagogical method so wrote a story that was a thought experiment in which students were invited to discuss their conceptions of an ideal city (consideration of the ideal is "disinterested" because it does not involve a particular situation in which interlocutors have stakes, which is to say that their consideration will, theoretically, be fair and unselfish). This disinterested, theoretical exercise in imagination was called The Republic...

Lionel Trilling echoes a moral of that story when he writes, "Unless we insist that politics is imagination and mind, we will learn that imagination and mind are politics, and of a kind we will not like" (2008:100). Understanding the need for imaginative, speculative exercise is important 
on many levels, including how it allows us to imagine the consequences of a given experience before taking action. It can also keep sight of the higher good and combat the otherwise potentially corrupting effects of politics and legislation. While imaginative exercise is not an example of problembased learning or practical experience, the imagination does build on the metaphor of $\tau \dot{\varepsilon} \chi v \eta$ (the practice of a craft), as mentioned above. This is to say that some practical experience is necessary before it can be abstracted. It is noted that while the shift from the particular or practical to the metaphorical or abstract "sounds philosophical", it can be explained in philological terms (e.g. Lakoff and Johnson: 1999, Lakoff and Turner: 1989).

Once experience is conceived of as a building block to be abstracted from, such as through the generalizing and abstracting functions, such as of $\vartheta \varepsilon \omega \rho i \alpha$ (theoria, contemplation, theoretic reckoning) - or through exposure to the multiple contexts afforded by wide reading which reveal "the effect of circumstance, the nature of partisanship, the role of chance, and the influence of leaders and bunglers", we can increase the chances of conceiving of a broader vision of society that is not destructive of individualities. This idea is purposely expressed in general terms here (also freely moving from Aristotelian to Platonic thought) because the goal of "common understanding", as Dewey puts it, is easily enslaved to partisanship, so it is posited here that the means by which to approach it are to be free flowing (see Arnold 1889: 155-156); not dogmatic. ${ }^{12}$

The broader social view - the philological promise - is grasped at, if it can be said to be reached, through the analytical tools that help us increase our chances to get the best out of experience and thought. Universities are to teach precisely those tools, and not once-and-for-all downloadable knowledge (see Carson 1999). There are bound to be spaces of $\dot{\alpha} \pi о \rho i \alpha$ (perplexity, impassibility) in all human endeavors, including where

12 This paper is circumventing discussion of the different approaches to thought in Aristotle and Plato, as well as related discussion of the theoretical and utilitarian: at once illustrating the indebtedness to tradition (footnotes like these are important), but allowing for a free flow approach to it. With regards to this paragraph: the idea of learning a craft to increase the chances of well-being is from Aristotle (1934: 1.10.13). Defense for taking a more theoretical approach can taken from Plato insofar as his dialectics is less a fixed system than a picture (Jowett 2008). Such felicity is bound to be limited, however, where theory is taught less as contemplative speculation than as dogma, as is the case with some contemporary theory (see Myers 1994 and 1999). 
mastery of society is sought. ${ }^{13}$ But perhaps an even worse consequence of pretensions of mastery aside from its blindness to what it does not know is that it is hostile to dialogue from the outset, as evidenced by how the Athenians dealt with the Melians. The sign of a true conversation, by contrast, is that it takes unexpected directions (Gadamer 2004: 361). This is because interlocutors who care about reaching understanding do more than merely convey their own point of view. They choose to submit to the influence of the truth of the subject matter and ultimately become "transformed into a communion" in which they do not remain what they were (Gadamer 2004: 371). Such a disinterested approach must be cultivated at universities if they are to remain in essence and not in name only.

Writing about the same time as Dewey, Rabindranath Tagore wrote that the problem of the present age is that differences need to be worked through in a disinterested manner in order to guarantee the perfection of unity, which "is not uniformity but harmony" (1922: 172). Tagore's directive can be taken as a description of what the ancients called modus vivendi. If only this could be bottled and sold. But it can be presented as a higher order skill to be aimed for in the backward design of curriculum.

Appreciating that knowledge can be contended is an important element in dialogic praxis. And it also suggests that true universality never needs entail the "breaking down of the walls of one's house" but can be maintained simply by offering "hospitality to guests and neighbors" (Tagore 1936: 568), which could be another way of saying entertaining their ideas - like how the oratory of yesteryear included concessions or rebuttals, or how Thucydides entertains a Melian idea while defending Athenian politics. Or like how philology has been antagonized in this presentation, having been called an old pain, but is ultimately championed. But hopefully this paper has shown that we will face a far bigger pain if university educators lack the capacity to account for difference as a matter of

13 Any form of mastery risks partiality, including the attempt to master a "broader social view", especially where this claims to be uninfluenced by trends. This is because "there is no stable point outside a culture from which to critique it" (Menand 2008: xii, also see Gadamer 2004: 83). Even Wenger concedes this is true: Wenger, whose theory underpins the networked program described in the problem-based illustration cited above, has acknowledged that his theory is not universally applicable. He amended his initial theory by suggesting that different theories be "plugged and played" to be better tailored to the sheer variety of different contexts that exist (Wenger 2010: 1). This footnote may be superfluous, however, in light of the legacy of postmodernism and relativism, which privilege doubt over the possibility of that which can be known objectively. 
practice, because, curiously, what has the greatest potential to keep mankind together is the analytical mind mature enough to grapple with a statement as paradoxical as enemies are but crude friends (see Velimirović n.d.: LXXV). Nobody said higher learning was easy or that it could be sold in a bottle. But snake oil, which is bottled and sold, claims that it can take away the pain.

\section{Bibliography:}

Aristotle. "Nicomachean Ethics". Aristotle in 23 Volumes, Vol. 19. H. Rackham (trans.). Cambridge, MA: Harvard University Press; London: William Heinemann Ltd., 1944. Perseus. n.d. Web. 5. 30. 2018.

---. "Politics". Aristotle in 23 Volumes, Vol. 21. H. Rackham (trans.). Cambridge, MA: Harvard University Press; London: William Heinemann Ltd., 1944. Perseus. n.d. Web. 5. 30. 2018.

Arnold, Matthew. Culture and Anarchy. London: Smith, Elder, \& Co., 1889. archive.org. 6.1.2010. Web. 5. 30. 2018.

Auerbach, Erich. "Philology and 'Weltliteratur.'” E. and M. Said (trans.). The Centennial Review, Vol. 13, No. 1 (Winter 1969).

Banfield, Ann. "I. A. Richards". Literary Theory and Criticism: An Oxford Guide. Patricia Waugh (ed.). New York, Oxford University Press, 2006.

Barzun, Jacques. Begin Here: The Forgotten Conditions of Teaching and Learning. Chicago and London: The University of Chicago Press, 1991.

Berry, Wendell. The Way of Ignorance. Emeryville, CA: Shoemaker and Hoard, 2005.

Carson, Ann. "The Idea of a University." The Threepenny Review, 73 (1999), 6-8.

Delies, Ineke. Stories about Connections: Regional Comakership. Leeuwarden/Groningen: Stenden Hogeschool and ROD Alfa-college, 2017.

Dewey, John. The Child and the Curriculum and The School and Society. Chicago and London: University of Chicago Press, 1966.

---. "The Need for a Philosophy of Education." The Later Works, 1925-1953, Volume 9: 1933-1934, Essays, Reviews, Miscellany, and A Common Faith. Jo Ann Boydston (ed.). Carbondale and Edwardsville: Souther Illinois University Press, 1986. 194-204.

---. The School and Society; Being Three Lectures, Supplemented by a Statement of the University Elementary School. Chicago: University of Chicago Press; New York: McClure, Phillips and Co., 1907.

Gadamer, Hans-Georg. Truth and Method. London, New York: Continuum, 2004.

Hadot, Pierre. The Veil of Isis. Michael Chase (trans.). Cambridge and London: Harvard University Press, 2006.

Hippocrates. "Aphorisms". A. Littré (trans.). Oeuvres Completes D'Hippocrate. Amsterdam: Adolf M. Hakkert, n. d. Perseus. 2005. Web. 5. 30. 2018.

Hormann, Shanna and Pat Vivian. Organizational Trauma and Healing. North Charleston, SC: CreativeSpace, 2013. 
Jowett, Benjamin. “Introduction." Phaedrus. Plato. gutenberg.org. 10.30.2008. Web. 5. 30. 2018.

Lakoff, George and Mark Johnson. Philosophy in the Flesh. New York: Basic Books, 1999. Lakoff, George and Mark Turner. More Than Cool Reason: A Field Guide to Poetic Metaphor. Chicago: University of Chicago, 1989.

Maylath, Bruce. "The Trans-Atlantic \& Pacific Project." ndsu.edu. n.d. Web. 9.18.2018.

Menand, Louis. Introduction. The Liberal Imagination. Lionel Trilling. New York: New York Review of Books, 2008.

Mousten, Birthe, Sonia Vandepitte, Elisabet Arnó, and Bruce Maylath (eds.). Multilingual Writing and Pedagogical Cooperation in Virtual Learning Environments. Hershey, Pennsylvania: IGI Global, 2018.

Myers, D. G. "Bad Writing". The Weekly Standard 4. (May 10, 1999). 36-39. weeklystandard.com. 10 May 1999. Web. 5. 30. 2018.

---. "On the Teaching of Literary Theory". Philosophy and Literature. Vol. 18, No. 2 (October 1994). 326-336.

Nietzsche, Friedrich. Daybreak: Thoughts on the Prejudice of Morality. R. J. Hollingdale (trans.). Cambridge: Cambridge University Press, 1982.

Plato. "Gorgias". Plato in Twelve Volumes, Vol. 3. W.R.M. Lamb (trans.). Cambridge, MA: Harvard University Press; London: William Heinemann Ltd., 1967. Perseus. n.d. Web. 5. 30. 2018.

---. "Meno." Plato in Twelve Volumes, Vol. 3. W.R.M. Lamb (trans.). Cambridge, MA: Harvard University Press; London: William Heinemann Ltd., 1967. Perseus. n.d. Web. 5. 30. 2018.

Ricoeur, Paul. A Ricoeur Reader: Reflection and Imagination. Mario J. Valdes (ed.). Toronto and Buffalo: University of Toronto Press, 1991.

Said, Edward. Preface. "Philology and 'Weltliteratur."' Erich Auerbach. The Centennial Review, Vol. 13, No. 1 (Winter 1969).

Sandys, John Edwin. A History of Classical Scholarship: From the Sixth Century B.C. to the End of the Middle Ages. Cambridge: Cambridge University Press, 1903.

Saussere, Ferdinand. Course in General Linguistics. Wade Baskin (trans.). New York: Philosophical Library, 1959. Web. n.d. archive.org 5. 30. 2018.

Tagore, Rabindranath. "An Eastern University". Creative Unity. London: Macmillan and Co., 1922.

---. “Dr. Rabindranath Tagore's Address". Benares Hindu University 1905 to 1935. V. A. Sundaram (ed.). Benares City: Rameshwar Pathak, The Tara Printing Works, 1936. archive.org. n.d. Web. 5. 30. 2018.

Thucydides. The Peloponnesian War. London: J. M. Dent; New York: E. P. Dutton, 1910. Perseus. n.d. Web. 5. 30. 2018.

Trilling, Lionel. "The Function of the Little Magazine." The Liberal Imagination. New York: New York Review of Books, 2008.

Velimirović, Nikolaj. Prayers by the Lake. Rt. Rev. Archimandrite Todor Mika, S.T.M. and Very Rev. Dr. Stevan Scott (trans.). sv-luka.org. n.d. Web. 5. 30. 2018.

Vico, Giambattista. "On the Heroic Mind". Elizabeth Sewell and Anthony C. Sirignano (trans.). Social Research Vol. 43, No. 4 (Winter 1976), 886-903. 
Von Humboldt, Wilhelm. "On Bildung". Teaching as a Reflective Practice: The German Bildung. Ian Westbery et. al. (eds.) New York: Routledge, 2010.

Wenger, Étienne. "Communities of Practice and Social Learning Systems: the Career of a Concept." Social Learning Systems and Communities of Practice. Blackmore C. (ed.). London: Springer, 2010. wenger-trayner.com. 2012. Web. 5. 30. 2018.

\author{
Грета Гец \\ Универзитет у Београду \\ Филолошки факултет
}

\title{
УНИВЕРЗАЛНОСТ КАО ИЗАЗОВ УНИВЕРЗИТЕТСКЕ МЕТОДОЛОГИЈЕ
}

\section{Сажетак}

Разматрање конструктивистичке епистемологије у погледу методологије, изгледа да имплицира да не може бити универзалних конструкција наставе и учења, посебно зато што се теоретичари и практичари разликују у смислу њихових педагошких, политичких и филозофских наклоности. Али ако треба узети у обзир корене и еволуцију саме речи «универзитет», универзитет као «заједница наставника и стипендиста» подразумеваће квалитете учења које деле сви људи, као што су објективност и учтиво дијалошко учествовање. Они доцнији допуштају постојање веће заједнице на првом месту, неговане кроз традиционално слободно образовање, слободно од робовања до неопходности. Рад ће истражити ове теме усредсређујући се првенствено на три различита мишљења: Ен Карсон, Рабиндранта Тагора и Џона Дјуиа. Ми ћемо испитати њихову заједничку мисао да искуство образовања мора захтевати «шири или друштвени поглед». Ово се постиже дозвољавањем умних нелагодности: «не треба брисати разлике» већ их ујединити држећи их нетакнутим - присуствујући узнемирујућим обавезама, а не само „улепшаним“ тврдњама о високом образовању. На тај начин се могу савладати потенцијална ограничења следбеничке конструктивистичке епистемологије. Ако се то учини претерано тешким, подржава чињеницу да се пут ка друштвеној свестраности налази на нивоу универзитетског учења. Методе за достизање су класичне, али и прогресивне.

Кључне речи: слободно универзитетско образовање, конструктивизам, епистемологија, свестраност, искуство, процес, пасиван план, Ен Карсон, Рабиндранат Тагор, Џон 